\title{
KESETARAAN DAN PERBEDAAN LAKI-LAKI DAN PEREMPUAN: KRITIK TERHADAP GERAKAN FEMINISME
}

\author{
Lina Gunawan \\ STT Reformed Injili Internasional
}

\begin{abstract}
This article, with a title: "The Equality and Distinction between Man and Woman: A Critique to the Feminist Movement", will firstly discuss about the feminist movement comprehensively and afterward it will discuss about the feminist movement within Christianity, genderequality issues, as well as the distinction between man and woman from the view of Christian feminism. After these, it will be discussed gender-equality issues and the distinction between man and woman from the perspective of Reformed theology. Then, a critique to the feminist movement within Christianity will be discussed. The finding of this article is that the feminist movement within Christianity has indeed grown a better appreciation for the woman, especially in the equality between man and woman. However, this movement ignores the distinction between man and woman which is a reality. The consequence is the authority of the Bible is accused by this Christian feminist movement.
\end{abstract}

KEYWORDS: feminism, Christian feminism, equality, distinction, Reformed theology.

ABSTRAK: Artikel yang berjudul "Kesetaraan dan Perbedaan Laki-laki dan Perempuan: Kritik terhadap Gerakan Feminisme" ini pertama-tama akan memaparkan mengenai gerakan feminisme secara menyeluruh, dan kemudian memaparkan mengenai gerakan feminisme dalam kekristenan, serta tema-tema kesetaraan, perbedaan laki-laki dan perempuan dalam pandangan feminisme Kristen. Kemudian dipaparkan mengenai tema-tema 
kesetaraan dan perbedaan laki-laki dan perempuan dari perspektif teologi Reformed. Setelah itu akan dipaparkan mengenai kritik terhadap gerakan feminisme dalam kekristenan. Temuan dalam tulisan ini adalah gerakan feminisme dalam kekristenan memang telah menumbuhkan kesadaran baru terhadap penghargaaan yang lebih baik terhadap perempuan, secara khusus dalam kesetaraan laki-laki dan perempuan. Namun, gerakan ini mengabaikan perbedaan laki-laki dan perempuan yang adalah sebuah realitas. Akibatnya, otoritas Alkitab mendapat gugatan dari gerakan feminisme Kristen ini.

KATA KUNCI: feminisme, feminisme Kristen, kesetaraan, perbedaan, teologi Reformed.

Gerakan Feminisme merupakan sebuah gerakan yang lahir pada abad ke-18, sebagai sebuah respons terhadap tatanan masa sebelumnya. Mulai saat itu muncullah istilah "feminisme". Lahirnya gerakan Feminisme ini seiring dengan timbulnya kesadaran baru terkait posisi sebagai sebuah pola relasi yang menempatkan laki-laki sebagai subyek, yaitu kaum superior yang mendominasi kaum perempuan. Jadi gerakan Feminisme adalah gugatan terhadap hegemoni laki-laki terhadap perempuan. Pada awalnya, tuntutan kaum feminis merupakan sebuah tuntutan atas hak dasar sebagai seorang manusia. Kaum feminis menuntut kesempatan berkiprah di bidang politik, pendidikan dan ekonomi. Namun dalam perkembangannya, tuntutan itu melampaui lebih dari sekadar hak dasar, di mana tuntutan itu juga menyangkut perlunya definisi ulang relasi antara laki-laki dan perempuan. Gerakan feminisme ini penulis sebut sebagai feminisme radikal. Tulisan ini akan memberikan kritik terhadap pandangan feminisme radikal tersebut, karena sekalipun kesetaraan jenis kelamin merupakan sesuatu yang dapat diterima secara umum, namun secara substansi, apa yang dituntut oleh kaum feminis radikal ini, dapat menimbulkan persoalan baru di dalam konteks relasi antara laki-laki dan perempuan. Periode yang 
terutama mempengaruhi pandangan Feminisme Kristen adalah feminisme gelombang pertama dan kedua. Dengan demikian penulis membatasi pembahasan ulasan tuntutan feminisme terkait relasi laki-laki dan perempuan hanya pada kedua gelombang Feminisme ini tersebut.

\section{Gerakan Feminisme}

Sejarah perkembangan Feminisme dapat dikategorikan di dalam tiga gelombang (waves). Gelombang pertama dimulai pada abad ke-18 dan ke-19, khususnya di Amerika dan Inggris, yang kebanyakan memperhatikan penderitaan universal dan hak untuk mendapatkan kontrak hukum dan ekonomi. Perjanjian pertama untuk kaum feminis diprakarsai oleh Mary Wollstonecraft, dalam bukunya: A Vindication of the Rights of Women (1792). Ia memperjuangkan hak perempuan untuk mendapatkan pendidikan dan posisi di masyarakat, dengan demikian perempuan bukan menjadi "ornamen" namun sebagai "pendamping" bagi suaminya. Ini ditulis sebagai respons untuk hak asasi manusia yang dicetuskan oleh Rousseau. ${ }^{1}$ Wollstonecraft dikenal sebagai orang yang berpengaruh untuk gerakan feminisme di Inggris. Sedangkan di Amerika adalah Elizabeth Cady Stanton (1805-1902) yang memenangkan hak perempuan untuk memilih, bersama Susan B. Anthony yang secara aktif memperjuangkan penghapusan perbudakan dan hak asasi perempuan. Stanton juga menerbitkan Alkitab Perempuan pada $1895 .^{2}$

Pada gelombang kedua, Feminisme berkembang pesat di tahun 1960 dan 1970-an. Selama perang dunia kedua, banyak kaum perempuan mengalami hidup di luar rumah dengan cara baru, mereka mendapatkan

\footnotetext{
1 Mary Wollstonecraft, A Vindication of the Rights of Woman: With Strictures on Political and Moral Subjects (New York: Bartleby.com, 1999), 118.

2 Anthony C. Thiselton, Hermeneutics: An Introduction (Grand Rapids: Wm B. Eerdmans Publishing Co, 2009), 283.
} 
pekerjaan yang vital dan kebebasan baru. Mereka dipengaruhi oleh tulisan Betty Friedan dalam bukunya Feminine Mystique tahun 1963 dan Perjanjian Kennedy yang membentuk komisi yang khusus membahas tentang status perempuan. ${ }^{3}$ Gelombang ketiga Feminisme terjadi tahun 1990-an. Isu yang muncul bukan isu baru, masih sama dengan isu sebelumnya, namun berkembang secara intensitas.

Dari apa yang diperlihatkan oleh gerakan Feminisme, tampak jelas bahwa apa yang menjadi tuntutan dan persoalan dari gerakan ini adalah kesetaraan antara laki-laki dengan perempuan. Menurut kaum feminis, apa yang disebut dengan kesetaraan jenis kelamin adalah sebuah tuntutan kesamaan hak baik laki-laki maupun perempuan di dalam setiap aspek kehidupan. Sekalipun kesetaraan jenis kelamin merupakan sesuatu yang dapat diterima secara umum, namun secara substansi, apa yang dituntut oleh kaum feminis, dapat menimbulkan persoalan baru di dalam konteks relasi antara laki-laki dan perempuan.

Pada awalnya, tuntutan kaum feminis merupakan sebuah tuntutan atas hak dasar sebagai seorang manusia. Kaum feminis menuntut kesempatan di dalam bidang politik, pendidikan dan ekonomi, namun dalam perkembangan berikutnya, tuntutan itu telah melampaui lebih dari sekadar hak dasar, di mana tuntutan itu juga menyangkut perlunya definisi ulang relasi antara laki-laki dan perempuan. Tentu saja, tuntutan ini mempunyai implikasi yang sangat luas bagi seluruh aspek kehidupan manusia.

\section{Kesetaraan Laki-laki dan Perempuan}

Kesetaraan laki-laki dan perempuan merupakan isu yang diusung Feminisme gelombang pertama. Feminisme menuntut kesetaraan di

3 Ibid., 284. 
berbagai bidang kehidupan, pendidikan, politik, ekonomi, dan sosial. Ini dapat dipahami karena pada awal abad pertama era Kristen, perempuan secara umum, mengacu pada Hawa sebagai pelaku dosa pertama, dipandang sebagai penggoda dan bermoral rendah. Pada tahun 1776, Abigail Adams, seorang istri anggota Kongres Amerika menulis kepada suaminya, John Adams, agar hak perempuan dimasukkan ke dalam hukum. Namun baru satu abad yang lalu perempuan memperoleh hak untuk memilih; memperoleh pembayaran yang sama untuk pekerjaan yang sama yang dilakukan oleh kaum laki-laki; dan juga bersama-sama dengan kebebasan manusia secara umum di Amerika. ${ }^{4}$ Feminisme gelombang pertama ini terjadi di Eropa dan Amerika. Para pejuang ini membentuk kelompok-kelompok untuk memperjuangkan hak perempuan. Mereka percaya bahwa perempuan akan menjadi warga negara yang mempunyai hak penuh di dalam hukum internasional jika mereka memperoleh kesetaraan di dalam pekerjaan, pendidikan yang lebih tinggi, akses memasuki ranah publik dan kebebasan memiliki materi. Mereka terus memperjuangkan hak pilih, tunjangan keluarga, penggunaan alat kontrasepsi, aborsi dan hak untuk memperoleh kesejahteraan bagi perempuan yang bekerja di rumah, undang-undang perlindungan dan status perempuan. Di ranah politik, kelompok-kelompok ini membongkar kekerasan dan perang internasional. Gelombang ini berhasil menciptakan identitas politik bagi perempuan, memenangkan kemajuan hukum dan juga emansipasi publik bagi perempuan. ${ }^{5}$

Semangat zaman ini mewarnai tulisan-tulisan beberapa tokoh yang memperjuangkan hak perempuan di gelombang pertama ini. Mary Wollstonecraft, seorang penulis dan filsuf Inggris abad ke-18, yang

\footnotetext{
4 Margaret Elizabeth Kostenberger, Jesus and the Feminists: Who Do They Say That He Is? (Wheaton, Illinois: Crossway Books, 2008), 17.

5 Maggie Humm, ed., Feminisms: A Reader (New York: Harvester Wheatsheaf, 1992), 11-4.
} 
memperjuangkan hak asasi perempuan, di dalam bukunya $A$ Vindication of the Rights of Woman (1792), berpendapat bahwa perempuan dan laki-laki mempunyai kapasitas yang sama, sebagai gambar dan rupa Allah, oleh sebab itu perempuan juga berhak memperoleh kesempatan yang setara dalam mendapatkan pendidikan, sehingga memungkinkannya mengembangkan kapasitas rasional dan moral, bukan hanya sensibilitasnya saja, untuk dapat mengembangkan potensinya menjadi manusia yang lengkap. Wollstonecraft menegaskan, perempuan yang sungguh-sungguh terdidik akan mempunyai kemampuan untuk mengatur rumah tangganya. ${ }^{6}$

Dalam dua abad setelah itu, kesetaraan laki-laki dan perempuan masih belum mencapai hasil yang maksimal seperti apa yang diharapkan dari perjuangan Wollstonecraft. Hal ini didapati oleh Maggie Humm di dalam tulisan Adeline Virginia Woolf, seorang penulis dan modernis yang juga berasal dari Inggris, A Room of One's Own (1929). Ia menggambarkan bagaimana perempuan masih didominasi oleh laki-laki, baik secara sosial maupun secara fisik. Perempuan menjadi korban laki-laki, oleh karena itu perempuan seharusnya menolak nilai-nilai dari masyarakat patriark. Ia berpendapat bahwa isolasi domestik dan isolasi profesionalitas perempuan adalah puncak dari dominasi material dan ideologi laki-laki terhadap perempuan, namun ironisnya, ia mendapati secara de facto, perempuan malah sebenarnya ikut 'berkolusi' dan punya andil juga di dalamnya. ${ }^{7}$

Pendapat senada juga dikatakan oleh Simone Lucie Ernestine Marie Bertrand de Beauvoir-biasanya dikenal sebagai Simone de Beauvoirseorang filsuf, aktivis politik dan feminis dari Perancis, di dalam bukunya Second Sex (1949). Pendapat ini dikutip oleh Humm, yang menyatakan bahwa masyarakat membentuk norma yang positif tentang laki-laki dan

\footnotetext{
6 Wollstonecraft, A Vindication of the Rights of Woman, 127, yang dikutip oleh Rosemarie Tong, Feminist Thought: A Comprehensive Introduction (Boulder, Colo.: Westview Press, 1989), 14-6.

7 Maggie Humm, ed., Feminisms: A Reader, 21.
} 
negatif untuk perempuan. Perempuan dianggap kelas dua, dan disebut sebagai "yang lain/liyan". Dalam tulisannya, Beauvoir membedakan antara jenis kelamin/gender (fungsi sosial) dan seks (natur perempuan). Di dalam fungsi sosialnya, perempuan saling bergantung satu dengan yang lainnya dalam fungsi keibuannya (motherhood), sedangkan di dalam hal natur perempuan, seseorang dikatakan sebagai perempuan itu bukan karena faktor biologisnya. Ia percaya bahwa tujuan revolusi perempuan hanya dapat dicapai dengan pembebasan perbedaan biologis dan pembebasan kemampuan rasional. De Beauvoir memberi kontribusi yang besar terhadap feminisme gelombang kedua, di antaranya pemikiran tentang adanya dikotomi antara perbedaan perempuan dan laki-laki, termasuk serangannya terhadap diskriminasi laki-laki secara biologis, psikologis dan ekonomis terhadap perempuan. Tulisan de Beauvoir ini mengantarkan feminisme kepada gelombang kedua. ${ }^{8}$

Di Amerika, Seneca Falls Resolution, "The Declaration on Women's Rights" (1848) yang memperjuangkan hak pilih bagi perempuan, pada umumnya dipercaya menjadi agenda yang membayangi gerakan feminisme liberal. Betty Friedan menjadi tokoh feminisme terkemuka di Amerika. Ia mendirikan The National Organisation of Women (NOW) tahun 1966, yang memperjuangkan kesetaraan hak sipil, kesetaraan akses untuk pendidikan, kesehatan dan kesejahteraan serta kesetaraan pembayaran upah bagi perempuan. Ia berpendapat, di dalam karya tulisnya The Feminine Mystique (1963), bahwa dengan hanya menjadi istri dan ibu bagi anak-anak, akan membuat perempuan menjadi bosan. Ia mengakui bahwa memang tugas ini adalah bagian dari hidup perempuan, namun bukan merupakan tugasnya sepenuh waktu. Perempuan harus mencari waktu untuk mengembangkan dirinya menjadi manusia yang utuh, yaitu dengan bekerja secara kreatif di

8 Maggie Humm, ed., Feminisms: A Reader, 44-5. 
luar rumah. ${ }^{9}$ Buku The Feminine Mystique yang pertama kali terbit tahun 1963 ini, dianggap sebagai pemicu munculnya feminisme gelombang kedua di Amerika abad ke-20.

Namun demikian, dua puluh lima tahun kemudian Friedan mempertimbangkan ada kesulitan dalam mengombinasikan antara pernikahan, menjadi ibu dan menjalankan karir secara sekaligus. Oleh karena itu di dalam tulisan selanjutnya yaitu The Second Stage, Friedan berpendapat bahwa Feminisme yang baru akan menuntut perempuan bekerja sama dengan laki-laki untuk melepaskan diri dari akibat yang ditimbulkan oleh Feminist Mystique, yaitu bahwa perempuan mengabaikan cinta, kasih sayang dan rumah. Ia mendapati bahwa perempuan tidak dapat dilepaskan dari kemanusiaannya di dalam kerangka hubungannya dengan laki-laki sebagai seorang istri, ibu dan perawat rumah. Dengan cara inilah, ia memperbaharui pemikirannya: bersama-sama dengan laki-laki, perempuan dapat mengembangkan nilai-nilai sosial, kepemimpinan dan struktur institusional sehingga memungkinkan kedua jenis kelamin ini mencapai pemenuhannya, baik di dunia publik ataupun di dunia privat, demikian yang dikupas oleh Rosemarie Tong dalam buku Feminist Thought. ${ }^{10}$ Di dalam karyanya The Second Stage, Friedan mulai menyadari bahwa pekerjaan tanpa keluarga justru akan membuat perempuan kesepian:

I was the first woman in management here. I gave everything to the job. It was exciting at first, breaking in where women never were before. Now it's just a job. But it's devastating loneliness that's the worst. I can't stand coming back to this apartment alone every night. I'd like a house, maybe a garden. Maybe I should have a kid, even without a father. At least then I'd have a family. There has to be some better way to live. ${ }^{11}$

\footnotetext{
9 Betty Friedan, The Feminine Mystique (New York: Dell, 1974), 69-70.

10 Rosemarie Tong, Feminist Thought, 24.

11 Betty Friedan, The Second Stage (New York: Summit Books, 1981), 20-1.
} 
Semangat zaman ini juga mempengaruhi gereja, khususnya perempuan dalam gereja secara teologis. Periode sejarah gereja, yang mengantar kepada Reformasi Protestan yang kepemimpinan gerejanya masih dipegang oleh laki-laki, adalah periode dimulainya kebangkitan feminisme. Reformasi itu sendiri mendorong setiap orang percaya membaca dan meneliti Alkitab, hal inilah yang membangkitkan benih yang membawa kesadaran akan nilai-nilai perempuan. Kesadaran inilah yang membuat sebagian perempuan, mengokohkan pendapatnya bahwa mereka mempunyai hak untuk berkhotbah dan mengajar. ${ }^{12}$ Terbukti dengan Grimke bersaudari, Sarah Moore Grimké (1792-1873) dan Angelina Emily Grimké (1805-1879), penulis, orator dan pendidik yang terlibat di dalam gerakan Quaker dan Abolitionist. ${ }^{13}$ Mereka memberi sumbangsih dengan menerbitkan risalah "Appeal to the Christian Women in the South" (1836) dan "Letters on the Equality of Sexes and the Condition of Women" (1837). Mereka masing-masing mengklaim bahwa Alkitab disalah mengerti dan salah interpretasi (tentang perempuan). ${ }^{14}$

Merebaknya perempuan yang aktif di dalam pelayanan kekristenan mencapai puncaknya di dalam tulisan Elizabeth Cady Stanton bersama dengan dua puluh penulis perempuan, The Woman's Bible $(1895,1898)$. Karya tulis ini lebih menyerupai buku tafsiran dibanding sekadar terjemahan. Stanton sendiri tidak menganggap Hukum Taurat Musa diinspirasikan, ${ }^{15}$ namun ia mengakui bahwa Alkitab melandasi hukum dan kebudayaan Barat yang didominasi oleh laki-laki. Ia percaya bahwa emansipasi

\footnotetext{
12 W. Baird, History of New Testament Research, Vol. 2: From Jonathan Edwards to Rudolf Bultmann (Minneapolis: Augsburg Fortress, 2003), 331-32, 335-37.

13 Quaker adalah sekelompok orang percaya dari berbagai denominasi di mana setiap orang yang tergerak oleh Tuhan boleh bicara memberitakan Firman dari Amerika Selatan pada abad ke-19. Abolitionist adalah yang menentang perbudakan dan memperjuangkan hak perempuan.

14 D.W. Dayton, Discovering an Evangelical Heritage (New York: Harper, 1976), 89-91.

15 Elizabeth Cady Stanton, The Woman's Bible (repr. New York: Arn, 1972 [1895]), 12.
} 
perempuan tidak mungkin terjadi jika posisi Alkitab tentang perempuan tetap diterima, karena Alkitab dianggap menjunjung kebudayaan patriark. Stanton memakai pendekatan "higher criticism"16 untuk mengikis otoritas Alkitab, terutama dalam hal pengajaran tentang perempuan. ${ }^{17}$

\section{Perbedaan Laki-Laki dan Perempuan}

Apabila pada gelombang pertama, feminisme membahas tentang kesetaraan dan perempuan mempunyai potensi yang sama dengan laki-laki, sedangkan pada gelombang kedua, pejuang feminisme justru lebih fokus pada perbedaan perempuan dengan laki-laki dan dengan perempuan itu sendiri, sebagai usaha menjadikan perempuan sebagai warga negara yang otonom. Gelombang ini mengarah kepada psikoanalisis juga kepada teori sosial tentang keberbedaan jenis kelamin untuk menciptakan etika feminist yang baru. Feminisme gelombang kedua menggunakan keberbedaan perempuan untuk melawan legalitas dunia patriarkal dan mengarah kepada formasi yang radikal. Argumen-argumen mengenai moral solidaritas yang diciptakan berdasarkan pendirian dan identitas pembela hak perempuan, 'reproduksi', 'pengalaman', 'perbedaan' menjadi isu penting di gelombang kedua ini. ${ }^{18}$

Feminisme gelombang pertama dan kedua sama-sama mendapati bahwa penindasan terhadap perempuan ini terkait pada seksualitasnya. Gelombang kedua mengambil isu reproduksi sebagai titik awal untuk memperjuangkan emansipasi di berbagai bidang. Para pembela hak perempuan percaya bahwa masalah takdir biologis inilah yang membuat perbedaan perempuan dan laki-laki, terutama di bidang ekonomi yaitu

\footnotetext{
16 Higher Criticism adalah kritik terhadap teks Alkitab dengan mempermasalahkan hal-hal lain di luar teks Alkitab seperti tantangan zaman yang terjadi saat itu, pengarang, sumber-sumber lain, sejarah, periode, dll.

17 M. E. Kostenberger, Jesus and the Feminists, 20.

18 Maggie Humm, ed. Feminisms: A Reader, 11-2.
} 
dalam hal pembagian pekerjaan dan sistem upah. ${ }^{19}$

Katherine Murray yang disebut juga Kate Millet, seorang penulis, pendidik dan feminis Amerika, dalam disertasinya yang akhirnya dijadikan buku "Sexual Politics" (1968), menyatakan bahwa identitas seksual ini bukan merupakan pengalaman natural dari perempuan dan laki-laki namun sebagai pembentukan dan dampak dari keadaan sosial dan politik, demikian yang dikutip oleh Humm. ${ }^{20}$ Millet berpendapat bahwa seks adalah politis, terutama karena hubungan laki-laki dan perempuan ada hubungannya dengan hubungan kekuasaan. Ia berargumen, jika penerimaan terhadap supremasi laki-laki yang dianggap sebagai hak sejak lahir tidak dihilangkan, maka semua sistem penindasan terhadap perempuan akan terus berlangsung. Karena kendali laki-laki di dunia publik dan privat menimbulkan kebudayaan patriark, maka penguasaan laki-laki harus dihapuskan. Dengan demikian, jika perempuan ingin mendapat kebebasan, maka harus ada penghapusan perbedaan jenis kelamin, terutama status, peran dan temperamen seksual (karena hal-hal ini telah dibangun di bawah sistem patriark). ${ }^{21}$ Para pembela hak perempuan di gelombang kedua ini juga berjuang menentang semua hal yang merendahkan perempuan seperti pornografi, perkosaan dan kekerasan terhadap perempuan.

Sama seperti Millett, Shulamith Firestone, seorang feminist radikal di Amerika, di dalam bukunya Dialectic of Sex (1970), mengatakan bahwa untuk menghasilkan jenis pembebasan manusia ini, dibutuhkan lebih dari revolusi biologis dan sosial yaitu dengan reproduksi buatan (ex utero) yang nantinya akan menggantikan reproduksi alami (in utero). Firestone berpendapat bahwa pada saat realita reproduksi biologis ini tertangani, maka perbedaan laki-laki dan perempuan dalam hal pengelompokan berdasarkan jenis

\footnotetext{
19 Ibid., 53.

20 Ibid., 260.

21 Kate Millett, Sexual Politics (Garden City, NY: Doubleday, 1970), 25.
} 
kelamin dan peran seksual dapat ditiadakan, sehingga pasangan heteroseksual bukanlah cara satu-satunya untuk memperoleh keturunan. ${ }^{22}$ Pada waktu Firestone menulis karyanya ini, teknologi yang baru dipakai secara luas adalah mengontrol reproduksi dengan kontrasepsi, sterilisasi dan aborsi, namun tiga dekade kemudian, teknologi reproduksi seperti inseminasi dari donor, bayi tabung dan transfer embrio sudah menjadi hal yang digunakan secara umum, demikian yang didapati oleh Tong dalam bukunya Feminist Thought. ${ }^{23}$ Dengan demikian, pandangan ini mengarah kepada homoseksualitas.

Mary Daly, seorang feminist radikal, yang mengajar di Boston College sejak 1967 sampai diberhentikan secara paksa tahun 2001, karena ia tidak mengizinkan mahasiswa laki-laki mengikuti kelasnya, ${ }^{24}$ sependapat dengan Firestone. Ia mengemukakan bahwa untuk memberdayakan perempuan sebagai manusia yang utuh, pembebasan kelompok berdasarkan jenis kelamin (gender) harus diberlakukan, bukan hanya di dalam wilayah manusia namun juga sampai wilayah Tuhan, hal ini ditemukan di dalam karya utama pertamanya Beyond God the Father: Toward a Philosophy of Women's Liberation. Ia berpendapat jika Tuhan tidak melepaskan diri-Nya dari keterikatan pada jenis kelamin tertentu maka perempuan tidak akan dapat menjadi seorang yang utuh. ${ }^{25}$ Daly memandang kebudayaan patriark memadamkan energi dan diri sejati perempuan, oleh karena itu ia berpesan kepada kaum perempuan untuk menghancurkan semua mitos, nama, ideologi dan struktur sosial yang dibentuk oleh laki-laki tentang

\footnotetext{
22 Shulamith Firestone, The Dialectic of Sex (New York: Bantam Books, 1970), 12.

23 Rosemarie Tong, Feminist Thought: A Comprehensive Introduction, 74.

24 Office of Public Affairs Staff, "Mary Daly Ends Suit, Agrees to Retire," The Boston College Chronicle 9, no. 11 (Feb. 15, 2001).

25 Mary Daly, Beyond God the Father: Toward a Philosophy of Women's Liberation (Boston: Beacon Press, 1973), 20.
} 
perempuan, ${ }^{26}$ serta menarik diri dari tuntutan laki-laki supaya perempuan sungguh-sungguh dapat menjadi manusia yang utuh. ${ }^{27}$ Dengan konsepnya ini, tidak mengherankan jika Daly 'memerintahkan' para feminist untuk menarik diri, bukan hanya dari institusi heteroseksual, tetapi juga seluruh institusi dengan sistem patriark, seperti: gereja, sekolah, organisasi profesional dan keluarga, demikian yang dikemukakan oleh Rosemarie Tong dalam Feminist Thought. ${ }^{28}$ Menurut Daly, hanya feminist lesbian radikal yang dapat bangkit mengalahkan pengalaman normal patriark laki-laki. Dengan pemikiran yang menghasilkan pandangan-pandangan yang radikal tersebut, Daly benar-benar terpisah dari kekristenan dan mewakili feminisme radikal di Amerika, demikian menurut pendapat Margaret Elizabeth Kostenberger tentang Daly. ${ }^{29}$

Dari pembahasan di atas, dapat disimpulkan bahwa pandangan Feminisme gelombang kedua semakin mengarah pada pandangan yang radikal. Hal ini juga mempengaruhi feminist Kristen di dalam membentuk teologinya terutama di dalam menginterpretasikan hal-hal yang berhubungan dengan isu kesetaraan, kepemimpinan perempuan dan peran perempuan di dalam sektor kehidupan sosial, politik dan agama. Gerakan kaum perempuan injili dimulai pada sebuah konferensi "Evangelical for Social Action" di Chicago pada tahun 1973, dan semenjak tahun 1975 sampai 1983 mulai berkembang, begitu pula ketegangan mengenai penafsiran Alkitab dan inerrancy, namun pada tahun 1986 terjadi perpecahan ketika ada perbedaan pandangan seputar isu homoseksual. Pada periode ini muncul dua organisasi di Amerika Utara, yaitu Christians for Biblical Equality (CBE), suatu advokat feminisme alkitabiah atau feminisme injili yang disebut juga

\footnotetext{
26 Mary Daly, Gyn/Ecology: 'The Metaethics of Radical Feminism (Boston: Beacon Press, 1978), 381.

27 Mary Daly, Pure Lust: Elemental Feminist Philosophy (Boston: Beacon Press, 1984), 366.

28 Rosemarie Tong, Feminist Thought: A Comprehensive Introduction, 126.

29 M. E. Kostenberger, Jesus and the Feminists, 53.
} 
egalitarianisme yang menekankan pada kesetaraan wanita terhadap laki-laki di berbagai bidang kehidupan. Sementara kelompok lain, yang berakar pada pendukung komplementer, menekankan adanya perbedaan antara laki-laki dan perempuan. Kelompok ini disebut The Council on Biblical Manhood and Womanhood (CBMW). ${ }^{30}$ Selanjutnya, perdebatan tentang jenis kelamin dalam hal peran laki-laki dan perempuan di dalam rumah, gereja dan masyarakat semakin meruncing di antara mereka.

Seiring berjalannya waktu, muncul tiga kelompok yang memperjuangkan perempuan: Radical Feminists, Reformist Feminists, dan Evangelical Feminists. Penjelasan secara sederhana, kelompok Radical Feminists menolak Alkitab dan menganggap kekristenan sebagai sesuatu yang sudah tidak lagi dapat dipakai karena pandangan yang bias tentang kebudayaan patriark. Sebaliknya, mereka berfokus pada pengalaman religius feminin sebagai kunci untuk menginterpretasi. Kelompok Reformist Feminists pada dasarnya menolak tradisi Kristen tentang perempuan, namun tetap menggunakan Alkitab sebagai sarana untuk merekonstruksi teologi yang positif secara "tepat". Bagi mereka, Alkitab itu sendiri tidak dilihat sebagai tulisan yang tidak mungkin salah (inerrant) atau otoritatif. Kelompok ketiga adalah kelompok Evangelical Feminist, yang mengatakan bahwa tidak ada yang harus ditolak dalam Alkitab, dan Kitab Suci dipandang sebagai pengajaran yang lengkap akan kesetaraan laki-laki dan perempuan. ${ }^{31}$

Perkembangan terbaru dari feminisme sering disebut sebagai Feminisme Gelombang ketiga, yang dimulai pada awal tahun 1990-an. Gelombang ini ditandai oleh pengejaran realisasi diri yang bahkan lebih

\footnotetext{
30 P. D. H. Cochran, Evangelical Feminism: A History (New York, London: New York University Press, 2005), 77-109 dikutip oleh M. E. Kostenberger, di dalam Jesus and the Feminists, 22-3.

31 Mary. A. Kassian, The Feminist Mistake: The Radical Impact of Feminism on Church and Culture (Wheaton, IL: Crossway, 1992), 249-50.
} 
radikal. Mereka menghilangkan prinsip-prinsip kekristenan secara sepenuhnya. Hal ini masih terus berkembang sampai sekarang. ${ }^{32}$ Isu yang diperjuangkan masih sama dengan gelombang kedua, namun lebih dalam secara intensitasnya.

\section{Laki-laki dan Perempuan dalam Perspektif Alkitab}

Laki-laki dan Perempuan Sebagai Ciptaan Allah yang Setara

Manusia yang terdiri dari laki-laki dan perempuan adalah makhluk ciptaan Allah yang dicipta dari tanah namun adalah ciptaan yang mulia karena diciptakan segambar dan serupa dengan Allah, Sang Pencipta itu sendiri. Di dalam Kejadian 1:27 yang mengatakan “Maka Allah menciptakan manusia itu menurut gambar-Nya, menurut gambar Allah diciptakan-Nya dia; laki-laki dan perempuan diciptakan-Nya mereka," Allah menghendaki manusia mengerti bahwa manusia, laki-laki maupun perempuan, adalah makhluk ciptaan yang setara secara martabat dan keberadaannya yaitu segambar dengan Allah, sang Pencipta. Richard Pratt di dalam buku Designed for Dignity mengatakan bahwa Allah tidak menjadikan Adam dan Hawa serupa dengan batu, pohon, dan binatang. Ia dengan begitu hati-hati membentuk laki-laki dan perempuan pertama itu supaya mereka menjadi serupa dengan-Nya. Ia memutuskan untuk menjadikan manusia sebagai ciptaan yang mempunyai nilai dan kemuliaan yang tiada tandingnya. ${ }^{33}$

R.C. Sproul menambahkan bahwa manusia, yang adalah gambar dan rupa Allah, memiliki kapasitas untuk berpikir rasional, berespon terhadap rangsangan dari luar dan mengolah pikiran kognitif untuk berpikir dengan logika yang baik. Hal itu dapat terjadi karena Allah memiliki pikiran, dan Allah-lah yang memberikannya kepada manusia. Allah mempunyai

\footnotetext{
32 M. E. Kostenberger, Jesus and the Feminists, 24.

33 Richard L Pratt Jr., Designed for Dignity: What God Has Made It Possible for You to Be (Phillipsburg: P\&R Publishing, 1993), 9.
} 
kehendak, dan Ia pun membuat keputusan, maka manusia pun demikian adanya. Manusia juga diberikan kemampuan untuk menunjukkan perasaan kasihnya, hal ini menunjukkan natur Allah yang ada di dalam kemanusiaan manusia. ${ }^{34}$ Laki-laki dan perempuan mempunyai kesetaraan di dalam semua kapasitasnya.

Lebih jauh, Agustinus mengatakan bahwa gambar Allah adalah sebagai refleksi dari tiga pribadi Allah yang tercermin di dalam kapasitas yang berbeda namun juga merupakan kesatuan dari memori, intelektual dan kehendak. 35 Anthony Hoekema menyetujui tentang konsep ini, ia berpendapat, ketritunggalan Allah didapati dalam hubungan laki-laki dan perempuan. Keserupaan manusia dengan Allah adalah di dalam laki-laki yang memerlukan persahabatan (companionship) perempuan. Laki-laki memerlukan perempuan dan perempuan memerlukan laki-laki. Hal ini merefleksikan hubungan yang erat (fellowship) di antara Allah Bapa, Anak dan Roh Kudus. 36

Sproul berpendapat bahwa Allah menciptakan manusia, laki-laki dan perempuan dengan nilai dan martabat yang setara. Mitos tentang subordinasi yang berarti inferioritas akan menghancurkan doktrin Tritunggal karena Allah Bapa, Allah Anak dan Allah Roh Kudus dipercaya sebagai Pribadi yang setara di dalam kemuliaan, kehormatan dan martabat, namun demikian masing-masing Pribadi tidak lebih rendah dari yang lain. Walaupun di dalam ekonomi karya keselamatan, Allah Anak taat (subordinasi) kepada Bapa dan Roh Kudus adalah subordinasi dari

\footnotetext{
34 R. C. Sproul, Truths We Confess: A Layman's Guide to Westminster Confession of Faith, Volume I: The Triune God (Chapter 1-8 of the Confession) (Phillipsburg: P\&R Publishing, 2006), 136.

35 St. Augustine, The Trinity: The Works of St. Augustine, Vol. 5, diterjemahkan oleh Edmund Hill (Brooklyn, NY: New City Press, 1991) dikutip oleh Bruce A. Ware: "The Glory of Man and Woman as Created by God" dalam Biblical Manhood and Womanhood diedit oleh Wayne Grudem (Wheaton: Crossway, 2002), 73.

36 Anthony A. Hoekema, Created in God's Image (Grand Rapids: William B. Eerdmans Publishing Company, 1986), 14.
} 
keduanya. ${ }^{37}$

Pendapat John Frame selaras dengan pendapat Sproul, ia mengatakan bahwa subordinasi tidaklah mengurangi kapasitas manusia sebagai gambar dan rupa Allah karena tiga hal. Pertama, manusia selalu ditempatkan di dalam hubungan yang merupakan subordinasi dengan orang lain, namun tidak merendahkan keberadaan mereka sebagai gambar Allah (contoh. Kel. 20:12 "Hormatilah ayahmu dan ibumu..."; Roma 13:1 "Tiap-tiap orang harus takluk kepada pemerintah yang di atasnya ..."; Ibr. 13:17 "Taatilah pemimpin-pemimpinmu dan tunduklah kepada mereka, ..."). Kedua, Yesus sendiri menjadi lebih rendah dari Allah Bapa dan bahkan ada di bawah struktur otoritas manusia, untuk menyelamatkan manusia. Oleh karena itu otoritas manusia, yang menyerupai Kristus adalah justru menjadi seorang pelayan (Mat. 20:26-28). Kerelaan untuk menjadi lebih rendah daripada yang lain demi Allah juga merupakan komponen dari gambar dan rupa Allah. Bahkan tunduk kepada otoritas yang tidak adil sekalipun menunjukkan keserupaan dengan Kristus dan mempermuliakan Allah (contoh 1Petrus 2:12) ${ }^{38}$. Ketiga, sangatlah sering terjadi, dengan merendahkan hati terhadap orang lain justru mendemonstrasikan komponen etis gambaran ilahi yaitu kasih, kesabaran, kelemahlembutan dan penguasaan diri Allah. ${ }^{39}$

Di samping argumentasi di atas, Wayne Grudem menambahkan bahwa di dalam konteks penulisan Kejadian 1-2, tindakan penamaan selalu

\footnotetext{
37 R.C. Sproul, Truths We Confess, 133.

38 "Milikilah cara hidup yang baik di tengah-tengah bangsa-bangsa bukan Yahudi, supaya apabila mereka memfitnah kamu sebagai orang durjana, mereka dapat melihatnya dari perbuatan-perbuatanmu yang baik dan memuliakan Allah pada hari di mana ia melawat mereka."

39 John M. Frame, "Men and Women in the Image of God" dalam Recovering Biblical Manhood and Womanhood: A Response to Evangelical Feminism, diedit oleh John Piper dan Wayne Grudem (Wheaton: Crossway Books, 1991), 228.
} 
dilakukan oleh orang yang mempunyai kekuasaan atas yang dinamainya. ${ }^{40}$ Hal ini mengindikasikan bahwa Adam yang menamai Hawa memang diberikan otoritas yang lebih tinggi daripada Hawa di dalam urutan penciptaan, namun demikian kesetaraan antara laki-laki dan perempuan tetap terlihat di dalam tindakan penamaan ini. Victor P. Hamilton, di dalam tulisannya tentang Kejadian 2:23, mengomentari bahwa dengan menggunakan dua kata yang berbunyi hampir sama yaitu laki-laki (ish) menamai perempuan (ishah), penulis kitab ini ingin menekankan identitas dan kesetaraan dari kedua makhluk ciptaan ini. ${ }^{41}$ John Calvin menambahkan bahwa pada waktu Adam menamai Hawa, ia mendapatkan penolong sepadan yang selama ini tidak didapatinya. Calvin mengatakan bahwa Adam melihat Hawa seperti melihat another self. ${ }^{42}$ Dengan demikian, laki-laki melihat perempuan sebagai makhluk yang sama/setara dengan dirinya.

\section{Laki-laki dan Perempuan Setelah Kejatuhan dalam Dosa}

Menurut John Calvin, manusia yang sudah jatuh dalam dosa tetap merupakan gambar dan rupa Allah. Gambar Allah tidak hilang namun bentuknya rusak secara mengerikan. ${ }^{43}$ Pikiran dan kehendak tetap ada, Calvin menyebutnya sebagai "karunia natural" (natural gifts), yang walaupun tidak hilang namun melemah dan rusak karena dosa. ${ }^{44}$ Walaupun demikian, Calvin menegaskan bahwa manusia harus tetap dihormati,

\footnotetext{
40 Wayne Grudem, Evangelical Feminism \& Biblical Truth: An Analysis of More Than One Hundred Disputed Questions (Sisters, Oregon: Multnomah Publishers, 2004), 31.

41 Victor P. Hamilton, The Books of Genesis: Chapters 1-17 (Grand Rapids: William Eerdmans Publishing Company, 1990), 180.

42 John Calvin, Genesis, A Geneva Series Commentary, terj. dan ed. John King M.A. (Edinburgh: Banner of Truth Trust, 1975, 1965), 13.

43 John Calvin, Institutes of the Christian Religion, ed. John T. Mc. Neill, terj. Ford Lewis Battles (Philadelphia: Westminster, 1960), I.15.4.

44 Calvin, ICR, I.2.12.
} 
dikasihi dan dibantu ketika ada yang memerlukan bantuan, karena biar bagaimanapun rusaknya manusia yang telah jatuh dalam dosa, ia adalah gambar dan rupa Allah.45

Frame menambahkan bahwa walaupun dosa merusak gambar dan rupa Allah, dosa tidak menghancurkan kemanusiaan manusia. Hal ini dapat secara tepat digambarkan dengan membandingkan hubungan Allah dan manusia dengan hubungan laki-laki dan perempuan. Sebagaimana Alkitab menekankan kemiripan antara Allah dan manusia demikian juga halnya antara laki-laki dan perempuan (Kej. 2:23). ${ }^{46}$ Keberadaan manusia adalah untuk 'membantu' Allah menggenapi rencana-Nya ${ }^{47}$ (Kej. 1:28) ${ }^{48}$, perempuan adalah untuk menolong laki-laki (Kej. 2:20) ${ }^{49}$, kedua hubungan itu disakiti karena dosa, tetapi kemiripan yang fundamental (fundamental likeness) yang menjadi dasar antara laki-laki dan perempuan tetap ada..$^{50}$

\section{Laki-laki dan Perempuan Setara dalam Anugerah Keselamatan}

Kesetaraan laki-laki dan perempuan juga terdapat di dalam laki-laki dan perempuan yang ditebus oleh Kristus, demikian yang dikatakan oleh Bruce A. Ware di dalam buku Biblical Manhood and Womanhood. Ia mengutip tulisan Paulus di dalam Galatia 3:26-29 "semua yang dibaptis dalam Kristus telah mengenakan Kristus, karena itu laki-laki dan perempuan sama, yang

\footnotetext{
45 Calvin, ICR, III.7.6.

46 "Lalu berkatalah manusia itu: "Inilah dia, tulang dari tulangku dan daging dari dagingku. Ia akan dinamai perempuan karena diambil dari laki-laki."

47 Walaupun sebenarnya Allah tidak perlu dibantu oleh manusia, namun Allah ingin menggenapi rencana-Nya melibatkan manusia sebagai alat-Nya.

48 "Allah memberkati mereka, lalu Allah berfirman kepada mereka: "Beranakcuculah dan bertambah banyak; penuhilah bumi dan taklukkanlah itu, ..."

49 "manusia itu memberi nama kepada segala ternak, kepada burung-burung di udara dan kepada segala binatang hutan, tetapi baginya sendiri ia tidak menjumpai penolong yang sepadan dengan dia."

50 John Frame, "Men and Women in the Image of God" dalam Recovering Biblical Manhood and Womanhood, 226.
} 
oleh karena iman disebut anak-anak Allah berhak menerima seluruh janji Kristus". Ia melihat, ide yang sama juga dikatakan oleh Petrus ketika memerintahkan para suami yang percaya untuk menunjukkan sikap hormat kepada istrinya sebagai teman pewaris dari anugerah kehidupan dalam Kristus (1 Pet. 3:7). Suami dan istri Kristen berdiri sama tinggi di dalam Kristus, keduanya diselamatkan oleh iman, keduanya dipersatukan dengan Kristus, dan keduanya adalah pewaris penuh kekayaan Kristus. Ayat-ayat di dalam Perjanjian Baru ini merefleksikan pengajaran Alkitab yang sangat jelas bahwa laki-laki dan perempuan setara di dalam kemanusiaannya (Kej. 1:26-27), oleh sebab itu setara juga di dalam kepenuhan karya penebusan Kristus bagi mereka. ${ }^{51}$

Menurut Calvin yang dikutip oleh T. F Torrance dalam bukunya Calvin's Doctrine of Man, penebusan adalah pembaharuan gambar Allah sebagai karya Roh Kudus, dikatakan bahwa "jika melihatnya dari sisi Allah, gambar Allah diperbaharui oleh Roh Kudus dengan memakai Firman Allah sebagai alat-Nya. Akan tetapi jika melihatnya dari sisi manusia, pembaharuan gambar Allah digenapi di dalam iman. Iman adalah suatu gerakan dari respons manusia terhadap Firman Allah yang olehnya manusia menjadi selaras dengan Allah yaitu gambar dan rupa Allah." ${ }^{52}$ Dengan perkataan lain, Roh Kudus memperbaharui manusia melalui Firman, dan manusia dimampukan oleh Roh Kudus berespons terhadap Firman melalui iman.

Frame menjelaskan lebih lanjut bahwa pembaharuan dan keselamatan itu adalah karya Allah yang digenapi oleh Allah Anak yaitu Yesus Kristus. Adam merusak gambar dan rupa Allah ketika jatuh dalam dosa, namun

\footnotetext{
51 Bruce A. Ware, "Male and Female Complementarity and the Image of God" dalam Biblical Foundation for Manhood and Womanhood, diedit oleh Wayne Grudem (Wheaton, IL: Crossway, 2002), 80 .

52 T. F. Torrance, Calvin's Doctrine of Man (London: Lutterworth, 1949), 80-1.
} 
Yesus, sebagai Adam kedua, menjadikan gambar Allah terhormat dan memuliakan Allah yang diwakili-Nya. Keselamatan memindahkan manusia dari kemanusiaan lamanya yang mati di dalam Adam, kepada kemanusiaan yang baru dan hidup di dalam Kristus (1 Kor 15:22) ${ }^{53}$. Melalui keselamatan, Tuhan menghapus distorsi gambar Allah karena dosa dan memimpinnya kembali kepada keserupaan Allah yang sempurna. Manusia diubah oleh Roh Kudus dengan kelahiran kembali dan pembaharuan hati, sehingga manusia mempunyai kapasitas, walaupun hanya untuk beberapa derajat, kembali mencerminkan dan merefleksikan karakter Allah. Itulah yang seharusnya manusia, yaitu laki-laki dan perempuan, lakukan sebagai gambar dan rupa Allah. ${ }^{54}$

\section{Laki-laki dan Perempuan Setara dalam Melaksanakan Mandat Budaya}

Allah menciptakan Adam dan Hawa dengan seluruh perlengkapan dan kemampuan yang dibutuhkan untuk merefleksikan kebenaran dan kesucian Allah yang sejati kepada alam ciptaan. Laki-laki dan perempuan yang setara sebagai gambar Allah, yang walaupun berbeda dalam perbedaan otoritas dan ketundukannya, dipanggil untuk menjadi wakil Tuhan atas seluruh ciptaan, mengamalkan kekuasaan, otoritas dan kehadiran Allah, yang dikenal sebagai tugas mandat budaya. (Kej. 1:28).55 Menurut Pratt, Allah sebenarnya tidak sulit untuk memenuhi bumi ini dengan hadirat-Nya, namun Ia memilih untuk menegakkan otoritas-Nya di bumi melalui cara-cara yang dapat dipahami oleh manusia. Seperti raja-raja zaman dahulu memenuhi kerajaan mereka dengan patung mereka untuk

\footnotetext{
53 "Karena sama seperti semua orang mati dalam persekutuan dengan Adam, demikian pula semua orang akan dihidupkan kembali dalam persekutuan dengan Kristus."

54 John Frame, "Men and Women in the Image of God" dalam Recovering Biblical Manhood and Womanhood, 226, (Italic ditambahkan oleh penulis).

55 John Frame, "Men and Women in the Image of God", 231-2.
} 
menyatakan kuasanya, Allah berkata "Bertambah-tambahlah dirimu, Aku ingin gambar-gambar-Ku tersebar di seluruh muka bumi." Demikian juga seperti seorang raja yang menganugerahkan otoritas kepada patungpatungnya, Allah memerintahkan gambar-gambar-Nya untuk bertakhta di atas bumi ini: "Taklukkanlah dan berkuasalah, Aku memberimu otoritas untuk menjadi wakil-Ku di dalam dunia-Ku" ${ }^{56}$

Pendapat yang terdistorsi tentang penciptaan Hawa adalah pernyataan bahwa Allah menciptakan Hawa sebagai hamba Adam. Sproul menjawab argumentasi ini dengan analogi yang tepat bahwa Allah menugaskan baik laki-laki maupun perempuan untuk menguasai alam (Kej. 1:28) dengan menjadikan Adam sebagai raja, yang wilayah kekuasaannya adalah bumi ini, dan Hawa sebagai ratunya (bukan hambanya). Raja dan ratu ini sepenuhnya menyatakan dan mempertunjukkan gambar dan rupa Allah. ${ }^{57}$ Jadi mereka adalah makhluk ciptaan yang setara.

Dari kenyataan bahwa Allah memberkati manusia dan memberi mereka mandat budaya (Kej.1:26-28), Hoekema berpendapat bahwa manusia juga menyerupai Allah sebagai pribadi yang bertanggung jawab, dan pribadi yang mempertanggungjawabkan segala sesuatunya kepada Allah sebagai Penciptanya dan Penguasanya. Di sini Allah dinyatakan sebagai sesosok pribadi yang dapat membuat keputusan dan memerintah. Hoekema meneliti lebih jauh tentang ayat 28, pada waktu Tuhan memberkati manusia untuk beranak cucu dan memenuhi bumi, hanya di sini, kata kerjanya di dalam bentuk jamak orang kedua, yang ditujukan kepada orang tua pertama di dunia ini. Perintah untuk beranak cucu ini menyiratkan adanya institusi pernikahan, yang Tuhan ciptakan untuk menjalankan mandat budaya ini. Dalam memberikan berkatnya, Allah tidak meninggalkan manusia, Ia berjanji akan memampukan manusia untuk

56 Richard Pratt Jr., Designed for Dignity, 22-3.

57 R.C. Sproul, Truths We Confess, 133. 
menguasai bumi dan beranak cucu yang akan memenuhi bumi. Di dalam berkat ini terkandung juga perintah atau mandat yang harus dilaksanakan oleh laki-laki dan perempuan untuk menguasai bumi dan untuk mengembangkan kebudayaan yang memuliakan Allah. ${ }^{58}$

\section{Kritik terhadap Feminisme}

Pandangan pejuang pembela hak perempuan memandang subordinasi dan dominasi laki-laki sebagai hal yang harus ditolak, karena subordinasi dimengerti sebagai inferioritas (lebih rendah) dan dominasi laki-laki dimengerti sebagai penindasan terhadap perempuan. Hal ini dapat dipahami karena sampai abad ke-18, perempuan mengalami tekanan dan tidak mempunyai kesempatan yang sama dengan laki-laki sehingga mereka sangat sensitif akan isu subordinasi dan dominasi laki-laki ini. Perjuangan kaum feminist merupakan reaksi dari suatu keadaan yang di dalamnya sudah terjadi penyimpangan yang berlebihan atas dominasi laki-laki terhadap perempuan. Mereka memperjuangkan kesetaraan perempuan dengan maksud kaum perempuan mendapat hak asasi yang seharusnya mereka dapatkan. Semua hal yang mereka lakukan diperuntukkan untuk mengangkat harkat perempuan yang sudah terpuruk. Namun, yang perlu diwaspadai di sini adalah mereka melakukan segala sesuatu atas nama perempuan. Hal inilah yang membuat pandangan dan cara pikir mereka tereduksi. Mereka melihat segala bidang kehidupan hanya dari perspektif perempuan, mereka menjadi sangat subyektif. Mereka bukan hanya memperjuangkan kesetaraan dengan laki-laki namun lebih jauh menolak dominasi bahkan menolak laki-laki itu sendiri. Hal ini dapat dilihat di dalam sejarah Feminisme bahwa perjuangan yang tadinya dilakukan untuk memperoleh hak asasi berubah menjadi gerakan yang menyimpang ke arah

58 Anthony Hoekema, Created in God's Image, 11-2. 
yang radikal. Terbukti dengan para pembela hak perempuan seperti Firestone yang berusaha untuk meniadakan perbedaan jenis kelamin dan menghindari pernikahan berbeda jenis dangan mengusahakan prokreasi dengan memproklamirkan teknologi reproduksi seperti: bayi tabung dan inseminasi buatan dari donor. Juga, Daly yang "memerintahkan" para penganut Feminisme untuk menolak segala institusi dengan sistem patriark.

Memang tidak dipungkiri bahwa teologi Feminisme Kristen ini telah membawa nuansa dan wawasan yang baru bagi gereja dan keluarga; para suami menjadi lebih menghormati istri mereka di dalam kehidupan keluarga dan membuat gereja melihat pentingnya memberi kesempatan yang lebih luas bagi perempuan mengambil bagian di dalam pelayanan gerejawi, demikian pendapat Wayne Grudem di dalam bukunya Evangelical Feminism: A New Path to Liberalism?59 Bahkan Richard Bauckham menambahkan bahwa ada wawasan baru yang dibukakan oleh para kaum terpelajar feminist dalam melihat para perempuan di dalam Injil, yang sebelumnya kaum terpelajar (scholar) laki-laki tidak menemukan bahwa bagian tersebut cukup menarik untuk diteliti. ${ }^{60}$ Namun ada masalah yang ditimbulkan ketika mereka melihat Alkitab dengan sudut pandang yang direduksi hanya dari perspektif perempuan saja. Menurut Bauckham, cara menginterpretasi yang digunakan oleh pembela hak perempuan ini adalah interpretasi 'kecurigaan' (hermeneutic of suspicion) sebagai prinsip yang mengontrol pembacaan teks di dalam Alkitab, sehingga hasil interpretasinya sudah diarahkan dengan pendekatan dan metodologi yang sudah ditentukan sebagai titik awalnya (the methodological starting point and approach). ${ }^{61}$ Inilah yang membuat pengertian dan pembacaan Alkitab

\footnotetext{
59 Wayne Grudem, Evangelical Feminism: A New Path to Liberalism? (Wheaton: Crossway Books, 2006), 11.

60 Richard Baucham, Gospel Women: Studies of the Named Women in the Gospels (Grand Rapids:

William B. Eerdmans Publishing Company, 2002), xiii.

61 Ibid., $x v$.
} 
menjadi berbeda.

Pendekatan yang digunakan para penganut Feminisme Kristen ini membawa pengaruh yang besar terhadap pengertian subordinasi. Pengertian subordinasi yang menempatkan perempuan lebih rendah dan menjadi kaum yang tertindas, membuat kaum pembela hak perempuan dan egalitarian melihat Alkitab secara berbeda, khususnya di dalam isu kesetaraan relasi laki-laki dan perempuan. Sebagai gambar dan rupa Allah, laki-laki dan perempuan setara sebelum kejatuhan. Namun setelah kejatuhan-di dalam pengertian penganut feminisme-perempuan menjadi lebih rendah, ketundukan kepada laki-laki dianggap kutukan sehingga menolak semua bentuk dominasi termasuk kekuasaan Allah. Hal ini membuat kaum pembela hak perempuan menempatkan laki-laki dan perempuan sebagai pihak yang beroposisi dan juga menempatkan perempuan beroposisi dengan Allah, Sang Pencipta. Pengertian subordinasi yang tidak tepat ini mempengaruhi seluruh pandangan kaum pembela hak perempuan tentang konsep keselamatan, posisi perempuan di dalam pernikahan dan juga pelayanan gereja. Mereka menolak semua bentuk ketundukan terhadap laki-laki. Di dalam keselamatan, mereka menyempitkan pengertian pemulihan ciptaan dalam konteks terbebas dari dominasi dan penindasan laki-laki bukan menitikberatkan pada restorasi ciptaan menjadi manusia baru di dalam hubungannya dengan Allah. Di dalam melaksanakan mandat budaya, perempuan, yang mempunyai kapasitas yang sama dengan laki-laki, diberikan tugas dan tanggung jawab yang sama. Perempuan dianggap mempunyai otoritas yang sama dengan laki-laki sehingga tidak perlu tunduk terhadap otoritas laki-laki. Di dalam perannya sebagai istri, kaum pembela hak perempuan mempertanyakan peran istri sebagai penolong dan ketundukan kepada suaminya, mereka menuntut ketundukan yang saling timbal balik dan menolak kepemimpinan suami sebagai kepala istri. Di dalam pelayanan gereja, kaum feminist berargumen bahwa larangan perempuan mengajar dan memimpin itu 
karena konteks yang terjadi pada saat penulisan Alkitab terjadi, dan bukan merupakan perintah yang universal karena perempuan juga harus diberi kesempatan yang sama dengan laki-laki dalam mengembangkan karunia yang Tuhan berikan kepadanya. Dari pembahasan ini, jelas terlihat bahwa pengertian subordinasi yang tidak tepat dengan wahyu Allah yang dikatakan di dalam Kitab Suci, berdampak besar dalam membaca dan mengerti Alkitab, terutama tentang relasi laki-laki dan perempuan ini. Secara umum, Campbell menyimpulkan feminists read Scripture through the screen of their own ideological convictions rather than reading Scripture itself. 62

Menurut pandangan Alkitab, subordinasi tidak berarti inferioritas. Allah menempatkan perempuan di dalam subordinasi terhadap laki-laki tanpa mengurangi nilai dan kemuliaannya sebagai gambar dan rupa Allah. Perempuan tidak perlu menolak kepemimpinan laki-laki karena perempuan tetap ciptaan Allah yang setara dengan laki-laki di dalam kapasitas dan di dalam melaksanakan mandat budaya. Di dalam keluarga, Allah telah menetapkan peraturan bagi suami tentang bagaimana memperlakukan istri dengan meneladani Kristus yang mengasihi jemaat dengan tanpa syarat. Perempuan ditempatkan di bawah kepemimpinan laki-laki dengan maksud untuk dikasihi, dilindungi dan diperhatikan kesejahteraannya bahkan suami harus rela berkorban untuk istrinya sama seperti Kristus yang rela berkorban untuk menyelamatkan gereja-Nya.

\footnotetext{
62 Cynthia M. Campbell, "Feminist Theologies and the Reformed Tradition" dalam Major Theses in the Reformed Tradition, Donald K. Mc Kim, ed. (Grand Rapids: William B. Eerdmans Publishing Company, 1992), 428.
} 